Persp. Teol. 33 (2001) 331-362

\title{
O MAL NOS DESAFIA
}

Nilo Agostini, OFM

\section{Introdução}

O ser humano quer ser feliz. Este é um desejo profundo e tem caráter universal. Não importam os desafios que tenha que enfrentar, nem mesmo eventuais derrotas. Sente-se impelido a construir algo e, com incansável ardor, a buscar o sentido da vida. Este desejo de realização e/ou de felicidade subjaz a qualquer vocação. Sente-se feito para ser feliz. Pascal já afirmara: "Todos os homens buscam ser felizes, mesmo aquele que vai se perder"'.

Este anseio vem acompanhado da busca de sentido, investindo num caminho próprio, no intuito de vencer na vida. Instala-se, no entanto, uma tensão, pois este ser humano descobre a distância entre a realidade cheia de desafios, revezes e até derrotas e o sonho de realização. Ante tal situação, alimenta mesmo assim a esperança de um dia ser feliz, apesar das provações do tempo presente.

Na realidade, o ser humano sente-se aquém, como que habitado por uma falta permanente de algo mais, sendo seu distintivo - como em todos os seres vivos - necessitar de outros seres e elementos da natureza para viver. Esta necessidade apresenta-se além da esfera do simples biológico e atinge uma gama variada de dimensões, abrindo-

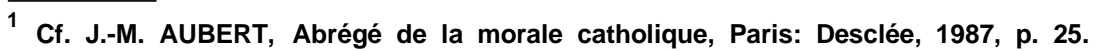


se à própria transcendência. A realização requer, portanto, o atendimento de necessidades que perpassam a sua integralidade, apontando para o fato de que ele é uma pessoa jamais acabada/completa. 0 ser humano traduz esta condição na busca de atender suas necessidades, sobre as quais projeta muito de sua ânsia de realização.

Este desejo é, no entanto, ilimitado. Manifesto desde a infância e acompanhando-o a vida toda, ele se apresenta qual sede, muitas vezes voraz, podendo ser procurado lá onde ele não se encontra cabalmente. Revela-se, então, a frustração ante a infelicidade, fruto de uma visão míope, distorcida, ou mesmo cega da realidade. Mesmo que o ser humano consiga atender momentaneamente um desejo, ele permanece insatisfeito, pois a cada necessidade satisfeita cria-se um novo desejo.

O desejo de consumir, a busca do poder, o absoluto da técnica são algumas da formas redutoras às quais, não raro, se entrega, hoje, o ser humano na ânsia de realização e de felicidade. Porém, ele não demora em descobrir a sua parcialidade, pois não preenchem a sua vida. Ao cair na ilusão de coisas finitas, dá-se conta, mais dia menos dia, de que estas são incapazes de responder à verdade de si mesmo.

Instala-se, então, um certo desencanto. Este é maior quando o ser humano se afronta com o mal nas suas variadas formas. Sentese atingido no seu âmago e nem sempre consegue explicá-lo convincente-mente. Condição ou deslize? Uma questão individual ou global/coletiva? A razão consegue dizer algo? E a experiência de fé? E... seu desejo de realização, não raro, esbarra nesta realidade do mal. Castigo, expiação? E o amor de Deus? Não há como prescindir desta realidade. Faz-se necessário enfrentá-la.

\section{O mal: uma realidade}

No ser humano, há uma frustração cuja origem remete ao mal. Pode chegar a comprometer a sua realização. É uma realidade sentida na vida do dia a dia que lhe surge como contraditória.

\subsection{Uma realidade sentida/vivida}

O mal apresenta-se ao ser humano como uma realidade e uma interrogação que o acompanha desde os primórdios. Os grandes textos fundadores de nossa cultura nô-lo apontam. Desde a Bíblia (em especial Gênesis, Salmos e Jó), passando pelas tragédias gregas e a literatura através dos séculos, perfilam-se interrogações, recriminações

e figuras terríveis para evocar o mal. 
Trata-se de uma constatação de todos os dias ${ }^{2}$. Aí estão diante de nós e em nós situações várias que evocam os escândalos de sofrimentos físicos e morais que nos tocam não só por todos os lados mas também no âmago de nós mesmos. Sentimo-nos dilacerados ante 0 espectro das mortes prematuras, da condição dos deficientes físicos e mentais, da crueza de solidões vividas, do esquecimento no qual são confinadas pessoas, sobretudo idosas.

Acrescentam-se aí formas variadas de racismo, a crueza da fome, a ausência de diálogo, as ameaças ao planeta em seu equilíbrio ecológico, as guerras de toda sorte. Os numerosos crimes e atentados contra a vida fazem soar aos nossos ouvidos o grito de alarme de uma situação que já ultrapassou os limites justificáveis e sustentáveis.

A vida humana, em particular, é violada de muitas formas, entre as quais destacamos "toda a espécie de homicídio, genocídio, aborto, eutanásia e suicídio voluntário; tudo o que viola a integridade da pessoa humana, como as mutilações, os tormentos corporais e mentais e as tentativas para violentar as próprias consciências; tudo quanto ofende a dignidade da pessoa humana, como as condições infra-humanas, as prisões arbitrárias, as deportações, a escravidão, a prostituição, o comércio de mulheres e jovens, e também as condições degradantes de trabalho, em que os operários são tratados como meros instrumentos de lucro e não como pessoas livres e responsáveis" ${ }^{3}$.

Caímos num desequilíbrio do que é vital. A própria natureza, ecologicamente falando, está sendo agredida em níveis insuportáveis, com uma degradação tão profunda que já se fala de um planeta Terra ferido de morte. Damo-nos conta dos limites da natureza; ela já não consegue mais absorver a quantidade elevada de gases, especialmente do gás carbônico ${ }^{4}$. 0 conseqüente aumento da temperatura atmosférica (efeito estufa), se atingir 2 a 3 graus centígrados, representará real ameaça à vida sobre a face da Terra ${ }^{5}$. Acrescente-se aí o problema da poluição atômica, sonora, das águas, bem como a contaminação da terra por inúmeros agentes químicos e plásticos não degradáveis.

\footnotetext{
${ }^{2}$ Cf. P. BIRMAN, R. NOVAES, S. CRESPO (Org.), O mal à brasileira, Rio de Janeiro: UERJ, 1997.

3 JOÃO PAULO II, Carta encíclica 'Evangelium Vitae' = Documentos Pontifícios n ${ }^{\circ}$ 264, Petrópolis: Vozes, 1995, $n^{\circ} 3$; CONCíLIO VATICANO II, Constituição pastoral 'Gaudium et Spes', in Compêndio do Vaticano II. Constituições, decretos, declarações, Petrópolis: Vozes, 1991, 22ª ed., $n^{\circ} 27$.

${ }^{4}$ A América do Norte, a CEI (ex-URSS) e a Europa são os que lançam mais CO2 na atmosfera, com taxas respectivas de 24,19 e $21 \%$ da emissão mundial. Cf. J. van KLINKEN, "O terceiro ponto no processo conciliar JPPC: A ecologia entre a teologia e as ciências naturais", Concilium 236 (1991), p. 76, nota 9.

${ }^{5}$ Tal aumento de temperatura atmosférica provocará a formação de desertos, fome generalizada, inundação de regiões litorâneas e muito populosas e destruição de habitats com extinção acelerada das espécies.
} 
A natureza tem seus limites e nós seres humanos também. Estamos ultrapassando os limites suportáveis. Já soou o alarme da crise ecológica, que aponta para uma simbiose entre o ser humano, a sociedade e o meio ambiente. $O$ espectro aumenta quando abordamos as grandes concentrações urbanas, o crescimento demográfico, o subdesenvolvimento, a pobreza, a habitação, a higiene, a saúde, o perigo de esgotamento de matérias-primas, as guerras etc.

Estamos, outrossim, tomando consciência de que o modelo econômico atual agride fortemente a vida neste planeta. Desenvolvido na civilização ocidental, hoje invadindo os mais recônditos lugares da Terra, este modelo corrói não só o humano mas desfaz o equilíbrio vital que une a natureza toda. A busca desenfreada do lucro, capitalizado/acumulado, levou a uma sede voraz de posse sobre a limitada natureza, hoje com sinais de depredação comprometedores. E mais! $\mathbf{O}$ alarmante ritmo de extinção das espécies não é um fenômeno natural, nem espontâneo e muito menos autônomo. Sabemos do enorme impacto causado pela interferência do ser humano na criação. Em curto espaço de tempo, estamos rompendo o equilíbrio que custou bilhões de anos para se formar e poder acolher/abrigar a vida ${ }^{6}$.

Com as técnicas modernas e respectivos conhecimentos científicos, o ser humano tornou-se capaz de intervir na natureza; transforma-a, submete-a, manipula-a, busca conhecer os seus segredos. Desde os primórdios da humanidade, ele vem realizando isso, buscando garantir a reprodução da própria espécie e a sua sobrevivência. No entanto, esta intervenção mostrou-se ambivalente. Por um lado, o ser humano foi capaz de dotar a humanidade de benefícios extraordinários. Por outro lado, na medida em que a sua intervenção mostrou-se voraz e desequilibrada, saltou aos nossos olhos a sua capacidade de depredar e destruir além dos limites ecologicamente suportáveis. Hoje, temos consciência de que este desequilíbrio está na raiz da crise ecológica e humana.

Não dá mais para tapar o sol com a peneira. 0 mal, sob formas variadas faz-se presente... e parece dominar. Não adianta fazer de

\footnotetext{
${ }^{6}$ Vejamos alguns exemplos de elementos que permitem a vida orgânica sobre a face da Terra, após bilhões de anos de "gestação" do seu habitat ideal. Esta vida aproveitou-se de toda uma constelação de possibilidades materiais, por exemplo, "ondas eletro-magnéticas para poder ver; ondas sonoras para ouvir; água, ar e terra para biótipos diversificados; os ritmos do dia e da noite, do verão e do inverno; aves que se movimentam pelo magnetismo da Terra; vida exige ozônio, dióxido de carbono (isto é CO2) e oxigênio em concentrações precisas; ozônio de menos e radiação solar ultravioleta destroem as moléculas orgânicas; ozônio demasiado torna-se um gás venenoso; CO2 é necessário para a vida com assimilação de carbono e para a estabilização da temperatura da atmosfera; o oxigênio do ar é um produto de vida e desapareceria sem a assimilação do carbono". Cf. ibidem, pp. 75-76.
} 
conta que tudo está bem, criando ilusões e simulando mundos paradisíacos numa fuga da realidade do mal que está aí diante de nós ${ }^{7}$. Constatamos um desequilíbrio do que é vital para nós. Vidas são excluídas e sacrificadas. Os indicadores econômicos e sociais em nosso país apontam para o escândalo moral que representam as desproporções existentes em termos de oportunidade de vida digna, no fosso entre riqueza e pobreza. A mentalidade calculista e tecnicista, aliada à rápida industrialização, está reduzindo o ser humano a peça de uma máquina de produção e consumo. $O$ individualismo exacerbado embaça nossa visão; elegemos o indivíduo como a medida de tudo, inclusive do que está além dele mesmo. A política continua sendo um palco privilegiado para nossas elites corruptas continuarem sua forma arcaica de domínio oportunista e irresponsável. Com isso, até a instituições andam debilitadas; sua legitimidade é posta em dúvida.

Este cenário coloca a modernidade, tão ciosa de sua emancipação, em crise. Na realidade, nos deparamos com um ser humano abandonado num caminho sem suporte adequado, passível de muitas quedas e capitulações, presa fácil de forças hegemônicas e muito bem apareIhadas que desejam sugá-lo sem escrúpulos, amarrá-lo em função de interesses traiçoeiros, ajustando-o e acomodando-o como "peça" do sistema, rebaixando-o assim ao estado de "objeto".

O mal campeia por todos os lados. Destroça a vida, depreda a natureza, desequilibra o humano em suas relações fundamentais. Quer fazer do próprio Deus um comércio lucrativo, no mercado onde a vida já foi sugada, a natureza tragada e a transcendência reduzida.

\subsection{Uma realidade contraditória}

Como vimos, o mal é antes de tudo uma constatação. Fere o ser humano em sua busca de querer viver, em seu anseio de realização e felicidade. $O$ mal apresenta-se como uma distorção, um verdadeiro obstáculo ao viver. Ele não é só carência; é também lesão, uma ferida que se abre e parece impossível de curar. Priva o ser humano do bem, do bem devido, cuja falta nega a vida. E, além disso, descobrimos a nossa impotência em fazer face a ele, como que nós também mergulhados nele ou parte dele e, por isso, fracos, impotentes, deficientes, sem saída, como se neste jogo as cartas já estivessem dadas, condicionando-nos sem mais.

Ainda mais. Constatamos facilmente como este mal se reproduz em cadeia e de maneira excessiva, fazendo com que a vida humana

\footnotetext{
${ }^{7}$ Cf. N. AGOSTINI, Teologia Moral: o que você precisa viver e saber, Petrópolis: Vozes, 2001, 6 ed., pp. 32-33.
} 
seja para muitos inviável e a luta para continuar a viver não só um tormento, mas ultrapassando as próprias forças. Encontramo-nos diante do "injustificável"8. É o contraditório dentro da experiência humana. Existe aí uma resistência inadmissível à vontade humana que anseia por realizar no concreto da vida um mundo aprazível. 0 sentido da vida parece escapar-Ihe entre os dedos.

Este excesso injustificável do mal transforma-o numa questão, no sentido de uma interrogação fundamental, de caráter ético, que pronuncia um veredicto: o mal é um escândalo! É isto mesmo o que a experiência do mal nos aponta, antes mesmo que nos debrucemos sobre explicações, aliás tão múltiplas e, por vezes, díspares no decorrer da história. Os discursos sobre o mal, desde os mais racionais, passando pelos míticos com suas "figuras" diversas, exprimem antes de tudo a inquietação do ser humano ante o não sentido do mal.

O escândalo do mal aparece, sob o ponto de vista humano, como "tudo aquilo que impede a humanização do homem", . Hoje, esta perspectiva vem sendo "corrigida e complementada pela visão ecológica da realidade que ressalta a importância básica da relação ser humanomundo da natureza, também no que se refere ao problema do mal"10.

\section{Tentativas de explicação}

Através da história, perfilam-se muitas e variadas tentativas de explicação do mal. Vamos percorrer algumas delas, abrindo espaço para analisar a realidade do mal na Sagrada Escritura.

\subsection{Através da história}

O mal desafia o ser humano a dar-Ihe uma explicação. São múltiplas e variadas, através da história, as tentativas de responder a este desafio. Entre estas podemos enumerar a explicação dos mitos, a perspectiva metafísica e várias tentativas modernas. São como que níveis diferentes na especulação sobre o mal.

O mito tem por função própria apontar tanto para o lado tenebroso quanto para o lado luminoso da condição humana. Incorpora a experiência humana do mal em grandes relatos da origem, chegando a

\footnotetext{
${ }^{8}$ Cf. J.-P. JOSSUA, “Mal”, in P. EICHER, Dictionnaire de Théologie, Paris: Cerf, 1988, p. 389.

${ }^{9}$ A. G. RUBIO, Unidade na pluralidade: o ser humano à luz da fé e da reflexão cristãs, São Paulo: Paulinas, 1989, p. 497.

10 Ibidem.
} 
localizar o mal antes mesmo da criação, no caos primitivo. Não se centra apenas no ser humano; inclui toda a criação, o cosmos. "Dizendo como o mundo começou, o mito diz como a condição humana foi concebida nesta sua forma globalmente miserável", afirma-nos Paul Ricoeur ${ }^{11}$.

A perspectiva metafísica interpreta o mal de formas diversas. Nela, identificamos uma tendência pessimista, à medida que ser é um mal. Quanto mais intensamente vivemos o ser, tanto mais fortemente experimentamos o mal e o sofrimento. 0 ser é aqui associado aos desejos (instintos e paixões) e às solicitações do mundo e da história. Importa buscar o não-ser, expurgando de nossa vida todo desejo, raiz do sofrimento. Entra-se, assim, num "nirvana".

Ainda na perspectiva metafísica, identificamos uma tendência dualista, para a qual a realidade atual é regida por dois princípios antagônicos: o bem e o mal. No mundo antigo, encontramos esta visão tanto no dualismo persairânico de Zaratustra e no dualismo platônico e neoplatônico gregos. Para Zaratustra, Ormus (luz) e Arimã (trevas) travam uma luta contínua entre si, repercutindo no ser humano que se sente, por isso, dividido entre o bem e o mal. No entanto, o bem vencerá no final. Para o platonismo e neoplatonismo, o mal consiste no fato do espírito deixar-se aprisionar pelo corpo e pela matéria. Importa esquivar-se da desordem material e das aparências sensíveis deste mundo degradado, para fazer reinar em si a virtude, em cujo centro está a idéia do bem e da justiça.

Há, igualmente, uma tendência otimista na perspectiva metafísica. Esta aponta para o ser como bom em si mesmo. Baseada na própria Sagrada Escritura, ela identifica a existência de um só Criador para todas os seres e, por isso, todos os seres que dele emanaram são ontologicamente bons. Lemos em $1 \mathrm{Tm}$ 4,4a que "toda criatura de Deus é boa". Esta passagem nos remete a Gn 1,31: "E viu Deus que era bom tudo quanto havia criado". Este otimismo, no entanto, ainda não dá uma resposta cabal ao problema do mal.

Entre as várias tentativas modernas de explicação do mal, destacamse as de Leibniz, do marxismo, da teoria da evolução e das ciências humanas. Esta escolha, é claro, não quer cobrir toda uma gama de posicionamentos muito variada. Para Kant, por exemplo, o mal moral é encarado como desobediência à lei moral que brota da razão humana (imperativo categórico). Hegel, por sua vez, situa o mal na liberdade humana, não em Deus.

\footnotetext{
${ }^{11}$ Cf. P. RICOEUR, Le mal: Un défi à la philosophie et à la théologie, Genève: Labor et Fides, 1986, p. 18.
} 
A escolha de Leibniz deve-se ao seu impacto no mundo Ocidental por construir uma visão otimista e defender Deus ante a existência do mal. Para ele, a existência do mal e Deus não são incompatíveis. Para chegar a esta afirmação, distingue os diferentes tipos de mal. Um é o mal metafísico, uma "privação do bem" (cf. Santo Agostinho e São Tomás de Aquino), um "não-ser", apontando para a situação criatural e finita inerente ao ser humano. Este limite não é em si um verdadeiro mal, fato que não responsabiliza Deus do mal existente. Outro é o mal físico, minimizado por Leibniz, pois Deus teria criado o melhor mundo possível, sendo o mal físico inerente às limitações do ser criatural que é o homem/mulher. Outro ainda é o mal moral (pecado); Deus o "permite" com vistas a um bem maior, não sendo Ele a causa deste mal que, nesta visão, será castigado e eliminado. Temos aqui a idéia de um universo harmonioso, sendo o mal insignificante diante da belíssima harmonia da criação, desejada por Deus.

O marxismo, bem a seu modo, situa o mal no plano puramente histórico sem referência ao transcendente. Para este, o mal deve ser enfrentado na história humana, com ênfase no nível estrutural, como fruto da infra-estrutura econômica que cria o mal maior da alienação. Importa investir contra o mal numa luta coletiva, guiada pelo proletariado, que se transforma em luta de classes. $O$ objetivo final é a supressão das classes, configurando-se aí a vitória contra o mal.

A teoria da evolução, por sua vez, apresenta o mal como subproduto inevitável de uma criação em fase de organização e realização, num vira-ser. A caminho da unificação, a fase atual paga o preço dos conflitos inerentes ao processo evolutivo, pois forças divergentes ainda se manifestam, entram até em conflito; há passos em falso, desordem, malícia, mal.

As ciências humanas sugerem uma visão do mal mais como "frustração", "disfuncionalidade", "anomia" etc. Pode ser situado no relacionamento entre o ser humano e o seu ambiente, na forma de condicionamentos diversos, ou no interior mesmo do ser humano, enquanto domínio dos instintos e agressão destrutiva (e não apenas funcional).

Mesmo trazendo contribuições relevantes, todas as explicações acima não dão uma resposta cabal à questão do mal. Às vezes, apresentam-se simplistas demais; outras vezes, incapazes de explicar realmente toda crueza do mal e do sofrimento no ser humano. Pode-se até resvalar no fatalismo (com Leibniz), numa visão limitada (com o marxismo), numa explicação insuficiente (da teoria da evolução), em visões fragmentadas (com as ciências humanas).

Continuemos a nossa investigação. Vamos, no ponto que segue, percorrer a Sagrada Escritura na captação da realidade do mal e na explicação que Ihe é dada. 


\subsection{A realidade do mal segundo a Sagrada Escritura}

A Sagrada Escritura capta o drama da existência do mal. Mostra, ao mesmo tempo, como Deus intervém para libertar o ser humano do mal, especialmente quando este é fruto do pecado e das suas conseqüências. No Novo Testamento, fica claro que a existência do mal deve ser tomada a sério, sobretudo na forma de pecado. Os Evangelhos sinóticos focalizam "a luta prática de Jesus contra 0 mal, a vitória sobre ele, bem como a atitude que devem adotar os discípulos de Jesus em face ao mal e aos maus" ${ }^{\prime 2}$.

Com São Paulo, se estabelece a realidade e o poder do pecado, no sentido do mal moral. Quando utilizado no singular, o termo pecado aponta para aquele "fechamento radical, fonte da má conduta moral e das diversas transgressões"13. 0 mais grave para São Paulo, reside no fato de que o mal é praticado "contra a vontade"14 do ser humano, identificando-o como expressão do seu próprio ser. Há algo de desconcertante na existência humana, pois, mesmo desejando o bem, eis que este ser pratica o mal. Há uma situação de incapacidade de vencer o mal. Só com Jesus Cristo, sua presença e a atuação de sua graça, é possível a vitória ${ }^{15}$.

Tanto para o Antigo quanto para o Novo Testamentos, o ponto central é a salvação oferecida por Deus. Mesmo que a experiência do mal ocupe um espaço importante, a suposição principal é a ação da graça de Deus que é oferecida gratuitamente, buscando resgatar o ser humano, pois este, sozinho, não é capaz de vencer o mal.

No entanto, o mal cria uma situação em contradição àquela realidade primeira, ou seja, da criação do ser humano à imagem e semeIhança de Deus. A morte, a inclinação para o mal e a incapacidade de evitar o pecado formam, assim, uma tríade de males que, entre outros, suscitam a pergunta pela origem do mal.

Podemos captar na Sagrada Escritura várias orientações sobre a existência do mal, cuja origem fica explicada das seguintes formas: o mal atribuído a Deus, o mal como desobediência humana, o mal como obra de Satanás, o mal como inerente ao ser humano, o mal como fruto do pecado original.

Todas as forças que operam na vida, tanto positivas quanto negativas, boas ou más, eram atribuídas a Deus pelo crente israelita. Ele

\footnotetext{
${ }^{12}$ H. HAAG, El problema del mal, Barcelona: Herder, 1981, p. 34; cf. A. G. RUBIO, Op. cit., p. 508.

${ }^{13}$ Cf. ibidem.

14 Cf. $\mathrm{Rm} \mathrm{7,} \mathrm{14-24.}$

15 Cf. $\operatorname{Rm} 7,25 ; 12,17.21 ; 1$ Cor 10,6 , etc.
} 
via em Deus "o primeiro fundamento, a única causalidade da sua vida"16. O próprio mal, quer físico, com mais freqüência, quer moral, com menos freqüência, é, portanto, interpretado como proveniente da vontade de Javé ${ }^{17}$. Na verdade, busca-se, com isso, ressaltar a total soberania de Deus em relação às criaturas. Entretanto, isso não chega a excluir a responsabilidade do ser humano, sobretudo quando se fala do mal moral, pois ele pode escolher entre o caminho do bem e o caminho do $\mathrm{mal}^{18}$.

Outra orientação bíblica aponta para o mal como castigo, conseqüência da desobediência humana. Isto dá-se quer rompendo a relação dialógica com Deus quer deturpando as relações fraternas na comunidade humana. Esta explicação encontra-se na origem do relato Javista de Gn 3 e 4. A intensa busca de explicação do mal, do sofrimento e, sobretudo, da morte leva o Javista a apresentar a condição humana real, ou seja, o ser humano necessita da misericórdia e do perdão de Deus para viver ${ }^{19}$. Por outro lado, deixa claro que é Deus Criador quem se opõe a toda sorte de maldades, buscando refrear o mal. Ao mesmo tempo, sublinha que Deus não abandona o ser humano, "Deus o sustenta, apesar de sua propensão ao mal”"20.

O mal como obra de Satanás é uma explicação tardia (pós-exílica). É mencionado no Antigo Testamento, porém tem toda a sua carga de tentador explanada no Novo Testamento. Ele é o tentador do ser humano, também de Jesus de Nazaré. $O$ pecado surge quando o ser humano cede à tentação de Satanás. Seu poder é apontado na linha do anticristo ou antidivino, porém nunca em pé de igualdade com Deus. A vitória é de Jesus Cristo, assegurada por sua morte e ressurreição, que aponta para a consumação plena na "Parusia".

A explicação do mal como inerente ao ser humano é outra perspectiva bíblica, sobretudo, presente na literatura sapiencial. "O sofrimento, as ambigüidades e os diversos males que afetam a condição humana são perfeitamente naturais, simplesmente fazem parte da criaturalidade própria do ser humano..., como mistério inescrutável para a limitadíssima compreensão humana... O próprio Jesus não aceita a crença popular segundo a qual todo sofrimento seria conseqüên-

\footnotetext{
${ }^{16}$ Cf. M. FLICK, Z. ALSZEGHY, Antropología Teológica, Salamanca: Sigueme, 1971, pp. 225-248; cf. A. G. RUBIO, Op. cit., p. 509.

${ }^{17}$ Cf., entre outros, Gn 32,23-33; Ex 4,24-26; Is 6,10; 1Rs 22,19-

22. ${ }^{18}$ Cf. Eclo 15,11-13.15-17.

${ }^{19}$ Cf. C. WESTERMANN, Mille ans et un Jour: I'histoire d'Israel miroir de notre temps, Paris: Cerf, 1975, pp. 22-25; A. G. RUBIO, Op. cit., pp. 510-511.

${ }^{20} \mathrm{C}$. WESTERMANN, Théologie de l'Ancien Testament, Genève: Labor et Fides, 1985, p. 150.
} 
cia do pecado (cf. Jo 9,3),21. É clássica, neste sentido, a reflexão sobre o sofrimento do livro de Jó.

A explicação do mal que ficou gravada mais fortemente na história e tradição eclesiais é, no entanto, a que relaciona a existência do mal com o pecado original. A origem do mal vem apontado como conseqüência do pecado cometido nos primórdios da humanidade. Os textos bíblicos clássicos que fundamentam esta explicação são Gn 3 e Rm 5,12-21. Coube a Santo Agostinho a explicitação e a formulação doutrinárias do pecado original na tradição eclesial. $O$ trabalho exegético e teológico não cessou, desde então, de buscar refletir sobre esta questão com desdobramentos diversos, mesmo permanecendo a afirmação fundamental aí existente. Vamos dedicar o ponto que segue a esta explicitação.

\section{O mal e o "pecado original"}

Estamos aqui diante de uma afirmação fundamental para a questão do mal. Mesmo assim, não é raro encontrar certa confusão e incerteza reinantes com relação à teologia do pecado original. Trata-se de um tema que não pode ser negligenciado por quem queira auscultar 0 mistério da salvação. Além disso, o pecado original nos ajuda a tratar devidamente o problema do mal bem como do próprio pecado.

\subsection{O pecado "originante/originado"}

Para alguns esse tema já se encontra claramente exposto nos cânones do Concílio de Trento. Outros acham que não adianta querer perscrutar um tema que nos escapa porque desembocamos naquilo que é um mistério insondável. No entanto, a coexistência do homem com o mal, quer na sociedade quer na sua própria pessoa, abre-nos à realidade de uma "estruturação" do pecado. Quando essa realidade atinge a pessoa humana (como capaz de praticar 0 mal), a teologia a denomina de pecado original.

Enquanto expressão em si, o "pecado original" não tem um sentido unívoco. Há dois aspectos conexos, mesmo que distintos. Tradicionalmente falamos em peccatum originale originatum (pecado original originado) para exprimir o estado, a situação presente do homem, a sua condição de pecador. Os teólogos modernos (como Schoonemberg) preferem falar de pecado do mundo. Há também a designação peccatum originale originans (pecado original originante - das origens,

${ }^{21}$ Cf. A. G. RUBIO, Op. cit., pp. 413-514. 
que dá origem) para designar o pecado de Adão. A mentalidade evolucionista e poligenista costuma ter dificuldades na abordagem desta segunda designação.

Os grandes pronunciamentos da Igreja sobre o pecado original foram feitos em meio a disputas cristológicas, trinitárias e antropológicas muito intensas. Buscando combater os erros dos adversários, a Igreja foi emitindo afirmações com acentos próprios, característico também das discussões realizadas em cada contexto. Por isso, as definições têm seu sentido mais clarividente quando entendidas dentro do contexto em que foram elaboradas. Mesmo assim, nos deixam dados fundamentais para a fé e para a compreensão tanto do mal quanto do pecado.

Os primeiros Concílios que abordaram a questão do pecado original foram os de Cartago (em 418) e de Orange ou Arausicano (em 529). Tem especial importância o segundo. Mesmo sendo de caráter local, recebeu a aprovação de Bonifácio II e teve uma ampla recepção em diferentes Igrejas. Entre as preocupações principais destes Concílios estava a de rechaçar o pelagianismo, o que Santo Agostinho assumiu com inegável virulência $^{22}$. A oposição entre Agostinho e Pelágio foi retomada ao longo dos séculos pelas disputas entre Bernardo e Abelardo, entre Lutero e Erasmo e, mais tarde, entre jansenistas e jesuítas ${ }^{23}$. Entrevemos nestas disputas diferentes visões subjacentes.

Pelágio, movido por elevado ideal ascético e desenvolvendo uma antropologia acentuadamente otimista, achou que o ser humano conseguiria, por si mesmo, evitar o pecado. Igualmente, conseguiria, por si mesmo, realizar o bem que o conduziria à vida eterna. Não seria necessária uma graça interna para combater o pecado. Como já podemos deduzir, este pensamento levou à negação da existência do pecado original, sendo o mal "algo natural" e a concupiscência uma realidade própria do ser humano. Esta visão esvazia a necessidade da redenção de Cristo e de sua graça oferecidas a todos (universalidade) ${ }^{24}$.

Para os seguidores do monge Pelágio, o pecado original não seria diferente do pecado atual. Ele seria mais um pecado "por imitação" do mau exemplo que nos deixou Adão e que atravessa as gerações. Os que não cometem pecados pessoais não são, portanto, afetados pelo

\footnotetext{
${ }^{22}$ Cf. I. SCIUTO, "Se Dio, perché il male?", in VVAA, Agostino e il destino dell'Occidente, Roma: Carocci Editore, 2000, pp. 61-77.

${ }^{23}$ Cf. J. I. GONZÁLEZ FAUS, Proyecto de hermano: visión creyente del hombre = Presencia Teológica no 40, Santander: Sal Terrae, 1987, pp. 336ss.

${ }^{24}$ Sobre a crise pelagiana, cf. D.-H. MARROU, "Dos primórdios a São Gregório Magno", in VVAA, Nova História da Igreja, Vol. I, Petrópolis: Vozes, 1966, pp. 405-413.
} 
pecado original. Isto é, as crianças podem ser batizadas por razões as mais diferentes, menos por causa do pecado original.

O Concílio de Cartago (418), por sua vez, afirma a necessidade do batismo para as crianças in remissionem peccatorum; isto é, elas contraem a culpa original na própria geração (cf. DS 222, 231). O Concílio de Orange explica, em 529, que o ser humano, em sua condição atual, não está intacto, mas em estado deteriorado, e sua liberdade não está ilesa, mas tomada pela corrupção (cf. DS 371,372 ).

O Concílio de Trento (1546) retoma as conclusões de Cartago e Orange ${ }^{25}$; nelas afirma o que, de maneira suscita, segue:

a) Pelo pecado, Adão perdeu a santidade e a justiça original em que fora constituído (cf. DS 1511);

b) A transgressão de Adão afetou toda a sua descendência e é transmitida por geração (e não por simples imitação) (cf. DS 1512, 1513);

c) Embora um na sua origem, o pecado se multiplica em cada novo nascimento (cf. DS 1512);

d) Trata-se de um verdadeiro pecado que só pode ser remido pelo batismo em Cristo (cf. DS 1514, 1515);

e) Pelo batismo, o pecado é totalmente perdoado, mas sobram suas conseqüências (uma inclinação para o mal) (cf. DS 1515).

Vemos que é de fundamental importância termos uma clareza sobre os principais textos bíblicos e conhecermos os caminhos abertos pela Teologia contemporânea.

\subsection{Os relatos bíblicos: Gn 3; $\mathrm{Rm}$ 5,12-21}

\section{Gênesis 3}

A estrutura básica deste relato aponta para a rejeição do convite de Deus por parte do ser humano. Este prefere a auto-suficiência, rejeita 0 diálogo com Deus e com os irmãos e deturpa o relacionamento com a própria natureza. No seu orgulho, o ser humano quer autonomia total, vira as costas para Deus, até cair em si e descobrir-se impotente, indigente, desamparado, nu, enfim, entregue à própria fraqueza. $E$, seguindo o pensamento de Santo Tomás, o ser humano mudou; conseqüentemente, mudou a sua percepção do mundo, dos outros seres humanos e de Deus. Etiologicamente, isto explicaria as suas tribulações, os sofrimentos e as fadigas no momento presente.

${ }^{25}$ Cf. A. MOSER, O pecado ainda existe?, Petrópolis: Vozes, 1977, 2ª ed., p. 49; cf. J. I. GONZALEZ FAUS, Op. cit., pp. 345ss. 
Não faltam estudos que tendem a afirmar que existe na base deste relato uma experiência de desvirtuamento vivida ${ }^{26}$ no tempo da monarquia. Os escribas da escola javista teriam trabalhado neste texto na época de Salomão, inclusive preocupados pela sedução com o "vinho de fora", dos povos vizinhos e seus cultos idolátricos ${ }^{27}$.

Buscando desentranhar esta experiência vivida, diz-nos José I. González Faus: "O conteúdo desta experiência é a monarquia que parecia 'muito boa', porque permitiu a expansão e o engrandecimento de Israel e até foi olhada como realização da promessa. No entanto, a monarquia era portadora dos germens de sua própria ruína (deterioração): o rei obrigará a um trabalho mais duro, se apropriará das mulheres para o seu harém e os filhos para suas guerras, dividirá Israel e provocará a inimizade de Deus. Os germens desta deterioração já estavam na origem mesma da monarquia, pois com ela o povo pôs sua confiança no rei mais que em Javé e preferiu ser mandado do que autogovernar-se. Diríamos em linguagem nossa, que a eficácia histórica falou mais alto do que a dignidade de povo. Deste modo, na origem mesma da realeza, se deteriorou a relação do povo com Deus: deixou de ser uma relação de responsabilidade; o povo preferiu entregar esta responsabilidade ao rei, sendo que teve que entregar-lhe também a liberdade: isto para 'ser como os outros povos' (1Sam 8,5), pois foi isto que fez grandes os outros povos. Porém, o que também faria aparentemente grande a Israel, embaralhará todas as relações ao interior do povo, pois Israel não foi eleito para ser 'grande', senão para ser 'povo', isto é, para ser fraterno",28. A “terra prometida” já pode pertencer a um clã, a um indivíduo ou ao rei e a sua corte (este detém o saber). Há um único exército. Tudo isso custa muito sacrifício ao povo. Também há problemas entre as tradições do norte e do sul.

\footnotetext{
${ }^{26}$ Carlos Mesters, ao analisar a narração de Gn 2,4-3,25, afirma ser este texto uma denúncia da situação desastrosa em que vivia o povo de seu tempo, buscando mostrar a raiz do mal detectado e a responsabilidade de todos pela situação, com o intuito de combater o mal e suscitar a confiança num Deus que é maior que os males. Por isso, segundo o exegeta acima, o texto apresenta o mundo dos seres humanos, com suas ambivalências, e o mundo desejado por Deus, este marcado pela harmonia entre o homem e a mulher, entre o homem, Deus e os irmãos, entre os homens e a criação. Cf. C. MESTERS, Paraíso terrestre: saudade ou esperança?, Petrópolis: Vozes, 13ª ed., 1991, pp. 27-39.

${ }^{27}$ Para José I. González Faus, este texto retrata, na verdade, a experiência de desvirtuamento vivida com a monarquia em Israel. $O$ texto seria da época de Salomão. Os escribas da escola javista que escreveram este texto nos mostram um Adão entronizado qual um rei. A centralização da humanidade em Adão só parece possível quando se tenha conhecido a centralização própria de um poder real. A noção de um jardim só pode brotar de um povo que já fez a passagem de tribo para um estado de sedentarizado. Os autores querem mostrar também que Israel fez essa passagem deixando-se seduzir pelo "vinho de fora", dos povos vizinhos, projetando isso como a sedução de todo gênero humano. Trata-se de explicar uma experiência vivida. Cf. J. I. GONZÁLEZ FAUS, Op. cit., pp. 325-326. 28 Ibidem.
} 
Seja qual for a leitura, o certo é que para o Antigo Testamento, "todos tomamos universalmente parte no que concerne o pecado, todos somos solidários, ao ponto de sermos um: Adão = todos os adãos"29. Se há uma solidariedade no mal, o AT busca também fontes que estão além dela, identificando aí as forças maléficas, demoníacas ou a cumplicidade com o mal que está dentro do próprio ser humano. No entanto, o AT enfatiza, sobretudo, (numa perspectiva moral) a responsabilidade pessoal do pecador: "Cada um é Adão por si". Adão emerge como o ponto de partida da corrupção de todo o cosmos.

Podemos concluir que no AT o pecado é, com freqüência, tematizado dentro da história, numa perspectiva situacional, buscando desentranhar por esta via o que seria o original do pecado original. Para 0 teólogo da moral, Antônio Moser, "o que é original em cada um de nós não se perde na noite dos tempos à raiz do nosso ser. $O$ original do pecado não é alguma coisa que viria juntar-se num segundo momento a nós, numa etapa determinada da vida... O original é alguma coisa que está já em nós pelo fato de existirmos, de sermos humanos. Está em nós não porque deveria estar, mas porque participamos de uma comunidade humana pecadora. $\mathbf{O}$ original do pecado original...

aponta forçosamente para o existente em cada um de nós, como inerente à nossa condição de ser-no-mundo"30.

\section{Romanos 5,12-21}

Este é um dos textos clássicos sobre o pecado original, especialmente pelo uso que o Concílio de Trento, entre outros, fez dele. Trento assume $\mathrm{Rm}$ 5,12 dizendo que "a Igreja difundida por toda a terra sempre o tem entendido desta maneira" (DS 1514). Sabemos, hoje, que esta leitura é devedora à compreensão de Santo Agostinho ${ }^{31}$. Para a leitura de Agostinho, influiu muito a sua compreensão do grego, explicitamente da sua tradução de eph'o (in quo) no pecado (= "no qual, em cujo pecado todos pecaram"). Posteriormente, Agostinho dá-se conta de que pecado, em grego, é feminino (em latim é neutro); por isso, ele traduziu "em quem" (= "em quem <Adão> todos pecaram" ou "nele <Adão> todos pecaram <originalmente>"). Esta tradução do relativo condiciona o verbo "pecar" referindo-o ao pecado cometido por todos em Adão, excluindo praticamente os pecados pessoais, quando o termo grego hermaton (= pecaram) os supõe (dos quais Paulo fala em Rm 1-2).

\footnotetext{
${ }^{29}$ P.-E. BONNARD, "L'Ancient Testament", in VVAA, Le péché originel: un dossier théologique, Lyon: PROFAC, 1978, 4ª ed., pp. 25-26.

30 A. MOSER, Op. cit., p. 48.

31 Cf. J. I. GONZÁLEZ FAUS, Op. cit., pp. 329ss.
} 
Existem ao menos três versões, dependendo do uso que se faz do relativo eph'o:

a) O antecedente é Adão: "O pecado entrou no mundo por um homem - em quem todos pecaram - e pelo pecado entrou a morte, e a morte passou para todos".

b) $O$ antecedente é a morte: "Por um homem entrou o pecado no mundo e pelo pecado a morte. E a todos a morte alcançou, por causa da qual todos pecaram".

c) Não há antecedente: "Por um homem entrou o pecado no mundo, e pelo pecado a morte, e a morte passou a todos, dado que todos pecaram".

A tradução da Vulgata assume eph'o em sentido relativo (in quo) e, portanto, referido a Adão. É esta versão que fundamentou a doutrina do pecado original ("no qual - Adão - todos pecaram) ${ }^{32}$. Com isso, a nossa situação pecaminosa atual não depende só dos nossos pecados, mas também do pecado do outro (Adão), anterior a nós. Deste texto e o de Gn 3, apreende-se que esta "situação" pecadora e miserável em que se encontra a humanidade atual não corresponde ao desígnio de Deus sobre o homem ${ }^{33}$.

Porém, o versículo 12, de $\mathrm{Rm} 5$, não deve ser tomado isoladamente. É importante enfatizar o paralelismo entre Adão e Cristo, pois coloca em evidência uma "afirmação didática básica do autor: a salvação obtida por Jesus Cristo é completamente universal" ${ }^{34}$. Toda a humanidade beneficiou-se da obediência de Cristo. Se na perdição todos os seres humanos estão "incorporados", o mesmo vale dizer da salvação em Cristo.

O pecado original precisa ser lido no âmbito da eleição gratuita de Deus, ou seja, numa perspectiva soteriológica. A graça de Cristo é indispensável a todos, pois existe em todos e em cada um de nós um mal do qual devemos ser salvos/redimidos. Sozinhos, sem Cristo, somos impotentes frente ao pecado que nos afeta. Portanto, este texto nos remete à graça, mais que o pecado, à redenção de Cristo que é explicitadora da graça de Deus ou da vida divina. Fomos redimidos em Cristo, e n'Ele somos co-herdeiros da herança divina.

Concluindo, diríamos que o ser humano é um ser pecador originário desde Adão e, ao mesmo tempo, um redimido em Cristo $^{35}$. É como

\footnotetext{
${ }^{32}$ Cf. A. G. RUBIO, Op. cit., p. 522.

${ }^{33}$ Cf. ibidem, p. 518.

34 Cf. ibidem, p. 517.

${ }^{35}$ Cf. K. RAHNER, "Pecado Original”, in Sacramentum Mundi, t. 5, Barcelona: Herder, 1972-1976, col. 338.
} 
afirmar que "existe um pecado particular, cometido nos inícios da história humana, que possui, por assim dizer, um estatuto especial, um influxo comparável ao da obediência de Cristo em ordem à salvação"36.

O Concílio de Trento ficou com a tradução in quo todos pecaram. Deste Concílio, importa reter aquele que é seu ensinamento fundamental, sua intenção básica ao se pronunciar sobre o pecado original. Esta pode ser resumida assim:

"O batismo liberta o homem de todo pecado (contra a justificação protestante)".

"Todo ser humano que vem a este mundo precisa do perdão de

Deus (doutrina do pecado original)".

“Propositalmente, o Concílio não se pronuncia sobre a essência do pecado original (questão discutida entre os teólogos) e, assim, faz uma descrição muito geral do mesmo, utilizando, para tal, o relato genesíaco do paraíso. No tempo do Concílio de Trento, este relato era compreendido por todos literalmente e de maneira fixista e, assim, o decreto tridentino não teria pretendido afirmar como doutrina de fé a historicidade estrita do relato"37.

\section{A eterna busca de impostações claras}

Continuamos nossa busca. Trata-se de ir desentranhando impostações que venham a elucidar sempre mais o fenômeno do mal em suas formas diversificadas. Este é um desafio sem igual lançado ao ser humano.

\subsection{Uma realidade a ser entendida em suas formas diversificadas}

Torna-se imperioso, a esta altura de nossa reflexão, superar as idéias distorcidas que temos do mal. Na própria linha dos Padres da Igreja, o mal não é uma coisa, nem um elemento do mundo ou uma substância em si. O mal tem sua raiz no exercício da liberdade, o que remete para um ser responsável. Portanto, não é, de per si, o mal "do mundo". Ele nem sequer reside na sensibilidade, no corpo ou na razão. Ele é sempre algo inscrito no coração do ser humano, enquanto

\footnotetext{
${ }^{36}$ M. FLICK, "Pecado Original", in Nuevo Diccionario de Teología, t. II, Madrid: Cristiandad, 1982, p. 1345.

37 A. G. RUBIO, Op. cit., p. 525; cf. M. FLICK, Op. cit., col. 1336.
} 
sujeito livre e responsável, portanto moral. Dizer sujeito é aqui sê-lo na "relação" que se estabelece diante de um chamado; é lembrar uma "eleição" que acaba por nos remeter ao próprio Deus.

A reflexão sobre o mal nos faz chegar àquela ruptura que se enraíza no ser, sem esquecer sua relação com o absoluto. Existe aí um apelo à transcendência, qual origem radical, irredutível, porém inscrita no tempo e na história na qual nos encontramos mergulhados. Buscando compreender melhor este contexto todo, a teodicéia tem tradicionalmente se debatido com as três afirmações: Deus é todo-poderoso; Deus é absolutamente bom; no entanto, o mal existe. Permanece o enigma para o ser humano que não consegue dar-Ihe cabalmente uma resposta. É, antes, um mistério no qual nos sentimos mergulhados.

Visto que o mal, como tantos outros termos, é uma palavra polissêmica, nós embutimos nela sentidos não raro díspares como o pecado, o sofrimento e a morte. Por isso, fazem-se necessárias algumas distinções básicas ${ }^{38}$. Uma primeira é a que distingue o mal físico do mal moral. No mal físico, podemos enumerar, entre outros, cataclismos naturais, epidemias, doenças incuráveis; produzem muito sofrimento de inocentes e apresenta-se como intolerável. 0 mal moral já aponta para aquele causado pelo ser humano mesmo, que chega a oprimir, espoliar, torturar seus semelhantes, tirandoIhes a esperança de realização. Neste nível, o sofrimento recai sobre quem não é responsável pelo mal praticado.

A análise do fenômeno do mal leva-nos a estabelecer igualmente uma distinção entre o mal cometido e o mal sofrido. Chegamos ao mal moral. A linguagem religiosa $o$ identifica com o pecado. Trata-se sempre de uma ação humana, passível de um grau de imputabilidade, de acusação e de censura. Quando falamos em imputabilidade, estamos nos referindo a um sujeito responsável, cuja ação é suscetível de apreciação moral. A acusação, por sua vez, aponta para uma ação que violou o código ético da comunidade. A censura representa o julga-mento e a respectiva condenação da ação que, declarada culpada, merece ser punida.

Mesmo que a punição, acima aventada, provoque um sofrimento, fazse necessário distingui-lo do pecado. A rigor, o sofrimento tem a característica de algo que nos afeta sem termos escolhido; dele somos vítimas. Podemos enumerar, neste ponto, as adversidades de natureza física, doenças do corpo e do espírito, aflições diversas, medo da morte, sentimentos vários. Opõe-se ao prazer, diminui a integridade física,

${ }^{38}$ Cf. P. RICOEUR, Op. cit., pp. 13ss. 
psíquica e espiritual. 0 sofrimento faz o ser humano vítima, diante do qual reage pela lamentação.

O mal está na raiz tanto do pecado quanto do sofrimento. No entanto, cabe distinguir o mal cometido e o mal sofrido. Identificamos, mesmo assim, que "uma causa principal de sofrimento é a violência exercida sobre o ser humano por outro ser humano: na verdade, 0 'mal fazer' é sempre, a título direto ou indireto, causar dano ao outro, conseqüentemente fazê-lo sofrer; em sua estrutura relacional - dialógica -, o mal cometido por este encontra sua réplica no mal sofrido por aquele; é neste ponto de interseção maior que o grito da lamentação é mais agudo, quando o ser humano se sente vítima da maldade do próprio ser humano"39.

\subsection{O mistério da iniqüidade - imersos no mal}

O ser humano, em sua condição mesma, sente-se como que tomado pelo mistério do mal ou da iniqüidade. Desde as raízes mais profundas de seu ser, descobre que algo há de confuso, assentado num fundo nebuloso. É como se forças superiores o seduziram, introduzindo-o numa história do mal, já, desde sempre para cada um em particular. Dáse conta que uma fissura o compromete na sua unidade profunda.

Ante este pressentimento, intervêm os símbolos e os mitos. Numa mediação da linguagem, eles buscam verbalizar o tremendum fascinosum da condição do humano que se revela, por um lado, luminosa, por outro lado, tenebrosa. As grandes narrativas das origens têm aqui a função de incorporar a experiência do mal, mesmo que fragmentária. Buscam explicar como a condição humana e o próprio cosmos trazem desde o início este traço globalmente miserável.

As grandes narrativas buscam dar uma visão englobante, oscilando entre o lendário e folclórico e a especulação metafísica. No seu lado folclórico, o mito formula uma linguagem capaz de recolher o demoníaco da experiência do mal. No seu lado metafísico, desenvolve, por sua vez, o especulativo, e chega à elaboração das teodicéias racionais, buscando refletir (responder) sobre a origem do mal.

Ao contar as origens, o mito busca explicar não só como a condição humana se encontra em tal situação, mas cabe-Ihe argumentar, explicando por quê tal situação é esta em cada ser humano ${ }^{40}$. Entra-se, então, no estágio sapiencial. Sua primeira formulação é a da retribuição, ou seja, merecemos o sofrimento por ser a punição por um pecado

39 Ibidem, p. 16.

40 Cf. ibidem, p. 20. 
(individual ou coletivo, conhecido ou desconhecido). Esta é a primeira formulação moral que, por sua vez, não resistiu a uma aplicação jurídica, ciosa de distinguir entre bons e maus e atribuir a punição a cada um segundo o seu grau de culpabilidade.

Com a crescente consciência da justiça, mesmo que inicialmente rudimentar, surgiu logo a constatação de que o mal se dissemina arbitrariamente, de maneira indiscriminada e desproporcional. Segue-se a indagação do por quê isto. Por que este mais que aquele é afetado por tal ou tais doenças? Por que morrem crianças, inocentes, indefesos? Por que tantos sofrimentos, excessivos à própria resistência dos humanos?

\section{Uma leitura histórico-antropológica}

O ser humano não esmorece em buscar decifrar a questão do mal. Lança-se em busca de sempre novas respostas. Bem recentemente, vimos abrir-se todo um campo de leitura que queremos apenas notificar. Através de uma leitura histórico-antropológica dos interditos, busca-se ir também às origens da humanidade e desentranhar a importância da proibição de matar e do incesto enquanto descoberta do outro.

\subsection{A emergência dos interditos ou a irrupção do "outro"}

A um certo momento da história dos seres humanos, irrompe o "outro" como interpelação e interrogação. $O$ livro do Gênesis (4,9-10) diz-nos como Deus interpela Caim: "Onde está o teu irmão Abel? O que fizeste?", "Que fazes tu do outro?" Voz da consciência, Lei inscrita no coração do homem por Deus, resposta desta consciência ao meio onde o ser humano vive e aos desafios deste: são algumas bases que nos levam a compreender a irrupção de dois interditos (não matar e o interdito do incesto), fundadores da relação com o "outro". Eles atravessam a história da humanidade e nos fazem compreender 0 nascimento e a subsistência do que chamamos de moral ${ }^{41}$.

A história evolutiva dos seres humanos nos mostra que estes viviam inicialmente da colheita de frutos e de cereais que encontravam na natureza. Em seguida, passam a ser predadores. E desta prática predatória passam à caça. Este último estágio supunha a descoberta e a utilização sistemática de ferramentas para matar, cortar e conservar. Uma reorganização social surge com a mulher mais voltada à colheita e o homem à caça.

41 Cf. P. RÉMY, Naissance de la morale, = Dossiers libres, Paris: Cerf, 1976. 
A invenção da ferramenta vem somar-se à descoberta da linguagem como manejo de um conjunto de símbolos mais do que uma cadeia de sinais. $E$, em seguida, os seres humanos serão capazes de comunicar-se por meio de palavras. Vemos aí 0 despontar da humanidade ela-mesma.

A evolução acima trazia um risco fatal. As armas usadas para caçar animais selvagens podiam ser usadas contra o grupo ou um de seus membros destruindo assim o equilíbrio natural. A violência mortífera e a ameaça de autodestruição punham em perigo de morte a humanidade desde os seus inícios. Diante desta possibilidade, num reflexo de sobrevivência, surge o interdito do assassínio (ou homicídio).

Convivendo/disputando um espaço com outros grupos semelhantes, a alternativa era a de aliança ou a de luta até a morte. A escolha veio a ser a aliança sob a forma de troca de mulheres, fazendo com que o casamento crie um eixo de relações entre os clãs e garanta a convivência pacífica. Sendo assim, interdita-se de esposar uma mulher do mesmo grupo (ou família). Dentro desse esquema, parece ter vivido o homem do paleolítico (antes do ano 5000 a.C.). As pesquisas e buscas diversas mostram que o seu habitat não comportava o elemento defensivo. Existia, é certo, as armas destinadas para a caça.

O período neolítico traz, no entanto, outras características. 0 aparecimento da agricultura, da criação de animais domésticos, dos vilarejos, 0 aumento demográfico perturbam 0 equilíbrio inicialmente adquirido. Um clima de guerra instala-se facilmente; testemunhas disso são as fortificações e as muralhas da época. 0 casamento passa a se realizar dentro do clã, da família, onde não se tem, contudo, notícia de que tenha sido tolerado um filho esposar a mãe (isto é, o incesto pai-filha e irmão-irmã tem sido tolerado por alguns grupos em certos períodos - foi o caso dos faraós do Egito, da aristocracia do Camboja...). Continua, portanto, como característica universal, a proibição de casar com a mãe. $O$ interdito do assassínio resiste também, pois matar um membro do clã ou do reino ao qual se pertence resulta em castigo/ reprovação.

\subsection{Não matar: suas múltiplas faces}

$O$ interdito de matar quer defender a vida, fazendo com que o meu semelhante continue de pé diante de mim. Proíbe, assim, a morte provocada por qualquer meio que seja (até aqueles meios que o progresso técnico-científico não cessa de criar e renovar). O agente direto ou cúmplice do desaparecimento de um ser humano é, num procedimento normal em todas as sociedades, responsabilizado, julgado, condenado. 
Há neste interdito um sentido e uma exigência que são afirmados como também velados. Afirma-se que a vida do semelhante deve ser respeitada. Vela outros sentidos e exigências, porque a morte violenta não é a única forma de desrespeito. Neste último caso, vemos que com o avanço e a complexidade da organização social, novos interditos surgem buscando explicitar aquilo que é necessário à própria subsistência. Busca-se garantir o direito de propriedade (mesmo que este se torne instrumento de dominação, 0 sentido primeiro continua); proíbe-se a mentira, a calúnia...

Além disso, sabemos que podemos matar através de uma ação, mas também por omissão. Leis, em muitos países, tentam evitar a recusa de assistência em caso de perigo. Nas sociedades industriais, as leis trabalhistas buscam, por sua vez, fazer com que o trabalho, único meio de subsistência (normalmente...), seja garantia da vida destes.

"Se matamos por ação, matamos também por omissão.

Se matamos com uma pancada, matamos também lentamente com o fogo por pequeno que seja, matamos com pontadas de agulha.

Se matamos a vida biológica, matamos também a vida afetiva, cultural, econômica, social, internacional.

Um educador pode ferir à morte, com uma palavra ferina, a criança que lhe é confiada. Um grupo social pode causar danos profundos à cultura de um outro grupo, pelo simples fato de propor, como única forma de cultura, a sua.

Pela estrutura de troca imposta aos países

subdesenvolvidos, os países que não o são freiam gravemente a expansão econômica dos primeiros.

Continuar indiferentes, deixar fazer, é ainda matar, por omissão, pois recusamos de dar assistência àquele que se encontra em perigo de morte, seja de uma morte rápida ou lenta" ${ }^{42}$.

Que fazes tu do outro? Não o mates, nem por morte, nem por omissão. Daqui nasce o engajamento moral com o protesto correspondente, fruto de uma consciência habitada pelo interdito do assassínio.

\section{3. $O$ interdito do incesto}

Vimos, igualmente, como nos primórdios da humanidade, a exogamia servia para criar entre os diferentes grupos um clima de paz

42 Ibidem, pp. 16-17. 
no lugar da guerra. Esta prática teria, igualmente, um resultado semelhante se o mesmo acontecesse, por exemplo, entre judeus e palestinos, entre etnias diferentes em países racistas. Reconhecemos, no entanto, que em nossa sociedade industrializada a paz é essencialmente baseada nas relações econômicas e culturais entre os povos. Reconhecemos, igualmente, o caráter regulador deste interdito para a vida familiar e para a educação dos filhos (evitando toda sorte de ciúmes, ódios e conflitos).

$\mathrm{Na}$ verdade, o interdito do incesto mãe-filho (pai-filha) foi o único universalmente respeitado. Este é o ponto de partida para o sentido que desenvolvemos a seguir. 0 primeiro passo será 0 de definir o sentido desta proibição.

O interdito do incesto proíbe um certo tipo de relação entre si e o outro. Para nós todos, o outro foi primordialmente a mãe, com a qual nós fazíamos uma unidade e tínhamos uma relação vivida em estado de plenitude, sem contrariedades, organicamente unida. Rompendo-se esse meio, a astúcia (manha) de nosso inconsciente leva-nos a buscar 0 que pode substituir a mãe. De maneira camuflada, continuamos aquela relação primordial. Este outro que escolhemos como substituto pode ser uma pessoa, um grupo social, um sistema de pensamento, até "Deus mesmo" etc. Isto para restaurar aquela relação a dois, onde não há nem coerção, nem obstáculos, nem contrariedades. No entanto, uma vez surgido qualquer tipo de ameaça, instaura-se um estado de confusão agressiva. $O$ integrismo, o sectarismo e o fanatismo têm aí uma de suas bases principais. $O$ problema está em abrir-se ao elemento terceiro ("ele"): o outro em sua originalidade (desafiadora), em sua situação, fora do âmbito de minha necessidade e/ou mesmice.

Quando a criança descobre que ela e a mãe não são uma coisa só e que, além disso, existe o pai, ela se vê obrigada a renunciar a esta relação exclusiva. No entanto, nela cria-se um estado de carência. Se antes a mãe era fonte de atração e de prazer, agora essa fonte são as pessoas, os objetos, as atividades, a realidade. $O$ olhar sobre as coisas busca captar o que a pode satisfazer/realizar. A carência, a "falta" nos relança, sob o signo do desejo e do prazer, na busca do real.

Pierre Rémy, em seu estudo já citado, diz sem rodeios que até certos tipos de piedade, de oração e certas místicas carregam uma imagem de Deus vinculada à busca de um estado de repouso, de paz, de calma, buscando pôr-se a salvo das preocupações cotidianas. Ele identifica aí uma relação incestuosa que deve ser rompida para voltar a colocar a fé como um desejo vivido no coração da vida real de todos os dias, e não à margem desta ${ }^{43}$.

43 Cf. ibidem, p. 21. 
Romper a relação incestuosa abre caminho para que a realidade afetiva inconsciente dê espaço para um pleno desabrochar e realização do desejo numa compreensão mais profunda da relação humana. Assim, romper a relação incestuosa com Deus é compreender que Ele nos convida a ir ao encontro dos outros homens para fazer com eles uma história a caminho da plenitude. Deus apresenta-se, então, como Pai de todos, nos introduzindo na dinâmica criadora e vivificadora...

$E$, conseqüentemente, faz-se necessário romper com outras modalidades de relação incestuosa, entre as quais com a Igreja e com o poder.

A relação incestuosa com a Igreja é rompida quando somos levados ao terceiro elemento, ou seja, a história concreta dos homens ao serviço da qual nos colocamos. Rompemos a relação incestuosa com o poder quando aceitamos o "pai", renunciando a usá-lo como uma dominação em função dos próprios interesses e necessidades para dar lugar ao terceiro elemento, ou seja, o bem comum.

Renunciar à possessão exclusiva porque o outro está aí. E este outro, eu não posso matar. Aqui está a ligação dos dois interditos. Podemos dizer também: Para que possa existir uma relação afetiva com o pai, com os irmãos e com as irmãs, faz-se necessário renunciar à relação incestuosa com a mãe.

Fundamentalmente, proíbe-se o desrespeito. Isso nos leva a encarná-lo na desafiante realidade do nosso dia a dia. Importa compreender, fazer compreender, interpelar numa abertura à diferença, num diálogo contínuo, numa conscientização crescente.

"Não mates este mundo que advém, esta geração diferente da tua que está surgindo! Abra-te à diferença, não tenha uma relação incestuosa com o teu próprio mundo cultural, como se não existisse outro além dele, como se tivesses que impô-lo aos outros, sem levar em conta seus direitos legítimos de pensar e de viver de outra maneira" ${ }^{44}$.

Vemos como o mal, numa leitura histórico-antropológica, pode ter nuanças muito sutis, porém não menos reais e comprometedoras da realização dos seres humanos. Também aí o mal é surpreendido em sua forte presença. No entanto, os dois interditos - do assassínio e do incesto - tiveram o mérito de ir se contrapondo ao mal já no alvorecer da humanidade. Há aí como que uma primeira forma de "salvação", um chamado à humanidade a aceder à graça do respeito, da vida e da paz, gestando a liberdade. Para aquele que crê, está aí um fruto da graça, um dom, fruto do Espírito de Deus já presente, Ele que desde os primórdios agia, suscitava, orientava, chamava..., inscrevendo no

44 Ibidem, p. 32. 
coração ou na consciência do ser humano esta "lei" não escrita, porém presente com toda força.

A vontade de Deus Criador encontra-se inscrita no ser humano, qual "lei natural". Este é um dado da revelação que atravessa o históricoantropológico. É o que lemos na carta aos Romanos: "O que se pode conhecer de Deus é manifesto entre eles, pois Deus Iho revelou. Sua realidade invisível - seu eterno poder e sua divindade - tornou-se inteligível, desde a criação do mundo, através das criaturas" ${ }^{45}$.

\section{O itinerário da fé}

A experiência de fé não nos desvia das questões suscitadas pelo mal. Coadjuvada pela razão, busca - tateando - a inteligibilidade possível ante esta realidade. Mergulha no mistério e encontra em Jesus Cristo o caminho seguro para fazer face ao mal.

\subsection{Um dilema insuperável?}

O ser humano sempre sonhou com a possibilidade de um mundo sem o mal. Porém, na vida factível/concreta, este ideal, como os demais, nunca se cumprem totalmente. "Por sua própria natureza, o mal aparece como facticidade irredutível e contraditória: como aquilo que não deveria ser e que, no entanto, é ${ }^{\prime \prime 4}$. 0 desejo de onipotência coloca o ser humano na ânsia, senão na pretensão, do tudo é possível. Faz-se, no entanto, necessário que ele se submeta ao princípio da realidade.

Outro dilema é o que introduz o mal na divindade. Neste momento, uma dificuldade acompanha a reflexão quer filosófica quer teológica. Ela vem apresentada como uma contradição, expressa no famoso dilema de Epicuro, que traz a seguinte formulação: "Ou Deus quer eliminar o mal do mundo, mas não pode; ou pode, mas não quer eliminá-lo; ou não pode nem quer; ou pode e quer. Se quer e não pode, é impotente; se pode e não quer, não nos ama; se não quer nem pode, não é o Deus bom e, ademais, é impotente - e isto é o mais seguro -, então, de onde vem o mal real e por que ele não o elimina" ${ }^{47}$.

Andrés Torres Queiruga traduz este dilema da seguinte forma: "Ou Deus pode e não quer evitar o mal, e então não é bom; ou quer e não pode, e então não é onipotente; ou nem pode nem quer, e então não

$45 \mathrm{Rm} \mathrm{1,18-20.}$

${ }^{46}$ A. TORRES QUEIRUGA, Do terror de Isaac ao abbá de Jesus, São Paulo: Paulinas, 2001, p. 182.

47 O. GIGON (Ed.), Epicurus, Zurich: Artemis, 1949, p. 80. 
é Deus"48. Logo damo-nos conta de que estamos diante de alternativas insuperáveis. Dada a visão da onipotência e da bondade divinas, a continuidade do mal no mundo seria explicado pelo fato de Deus onipotente não querer eliminá-lo. 0 mesmo afirmar-se-ia do Deus bom que, ante a persistente presença do mal, não poderia então evitá-lo. Nota-se que, nesta argumentação, permanece o pressuposto de um mundo sem mal.

Muito se tem escrito ao longo da história no sentido de que Deus não é a fonte do mal. No entanto, numa investida especulativa, são muitos os autores que permanecem apenas em indicações ${ }^{49}$, haja vista a dificuldade de uma leitura mais aprofundada em face aos dilemas que logo aparecem, como vimos acima. Mesmo assim, vamos trazer à tona algumas explicitações que nos auxiliam a dar mais alguns passos nas questões aqui levantadas.

Entretendo-se com a questão acima, Santo Agostinho pensa Deus como vere esse e summum bonum ${ }^{50}$. Em Deus, o Ser e o Bem coincidem, formando uma Unidade. E os seres da criação são bons em si porque derivam deste Uno, sendo o mal nada mais do que a privação do ser. Entendemos, então, que para este Autor o mal seja entendido como privatio boni. Por outro lado, Santo Agostinho desdobra a sua teodicéia colocando um peso decisivo na voluntas, ou seja, encontra na vontade livre a resposta para o significado moral do mal.

Esta visão de Santo Agostinho move-se dentro da noção de uma "ordem" que tudo governa, sendo o mal externo à ordem. É o mesmo que dizer que o mal é uma desordem, não porque o seja ontologicamente, mas porque o é numa dimensão moral. No entanto, ao cair no mal, inicia-se no ser humano um processo de depauperamento ontológico. Ocorre uma corrupção no ser, no sentido de uma privação (ou, o que se opõe à natureza), nunca no sentido de gerar uma segunda natureza ${ }^{51}$. Se o fundamento de toda realidade é Deus, o mal aparece como uma deficiência ontológica. Ao mesmo tempo, sendo o ser humano dotado de uma vontade livre, esta se torna a causa positiva e primeira do mal, sendo este envolto, portanto, de um significado essencialmente moral. Mesmo assim, há algo que precede $o$ ato voluntário (moral) e que atinge o ser na sua origem, na sua radicalidade, e que vai além de sua própria vontade. Neste caso, Agostinho se detém no conceito de pecado original.

48 A. TORRES QUEIRUGA, Op. cit., p. 187.

${ }^{49}$ Cf. J. BERNHART, "Mal", in H. FRIES (Dir.), Encyclopédie de la foi, t. III, Paris: Cerf, 1966, p. 16.

50 Cf. S. AGOStinHO, De moribus Manichaeorum, I, I; cf. Idem. Confissões 4, 6.

${ }^{51}$ Ita et malum ostenditur quomodo dicatur; non enim secundum essentiam, sed secundum privationem verissime dicitur. Cf. Idem, De moribus Manichaeorum, 4,6. 
Hoje, busca-se esclarecer as questões de fundo superando posições extremas. Cuida-se para não cair numa postura de "fracasso de toda teodicéia", de refúgio no "fideísmo", de acentuação do mistério e sua incompreensibilidade ${ }^{52}$. Faz-se necessária uma nova formulação que explique o problema do mal em si mesmo, buscando desentranhar o mal na sua causalidade histórica e mundana. Tal análise dá-se logo conta da limitação da realidade mundana, não porque é má em si mesma, mas por sua condição de possibilidade, sendo inevitável a aparição dos males no concreto de nossa existência. Isto é o mesmo que afirmar que estamos numa realidade finita e carencial. A própria liberdade do ser humano é limitada e, conseqüentemente, realiza-se entre erros, deficiências e conflitos.

Portanto, um mundo finito e perfeito ao mesmo tempo é uma contradição. Seria o mesmo que afirmar um círculo-quadrado. Andrés Torres Queiruga é que desenvolve esta impostação, enfatizando que "a realidade enquanto finita... é incompatível com a perfeição plena e com a exclusão de todo o mal" "53. Assim, superamos o equívoco e o absurdo de querer "culpar" Deus pelos males, já que estes são inerentes a toda realidade finita. "Deus 'não pode' fazer um círculo quadrado. Deus 'não pode' fazer um mundo sem mal. Um mundo sem mal seria, a rigor, um mundo perfeito; um mundo perfeito seria um não-mundo, isto é, uma contradição, um círculo-quadrado. Que Deus não o faça não significa que 'não queira', mas que 'não pode'; não porque ele não seja onipotente, mas porque a proposição é absurda" ${ }^{254}$.

A realidade finita é em si boa, porém "afetada" pelo mal. Ela é boa, porém não de modo cabal; há nela algo de não acabado e não pleno. Ela é afetada pelo mal, enquanto condição de possibilidade; isto é, em algum momento pode surgir o mal, quer na forma de mal físico (por limitação material, por exemplo, dois corpos se chocam porque não podem ocupar o mesmo lugar, daí acidentes diversos...), quer na forma de mal moral (no exercício da liberdade, quando esta cede e esco-lhe a pior dentre duas ou mais escolhas).

Podemos afirmar, então, que "Deus quer o mundo por si mesmo, apesar da finitude e do que ela comporta, pois a finitude não é um 'meio para', mas a coisa mesma concretamente, é seu único modo possível de existir... 0 mal impõe-se como um inevitável 'apesar de'; mas justamente 'apesar do mal', o ser e o bem são e se afirmam. 0 'não-dever-ser' do mal revela-se, assim, como o dinamismo da realida-de rumo à sua máxima realização possível..., ${ }^{55}$.

${ }^{52}$ Cf. A. TORRES QUEIRUGA, Op. cit., pp. 190-204.

${ }^{53}$ Cf. ibidem, p. 212.

54 Idem, "Mal", in VVAA, Conceptos fundamentales del cristianismo = Estructuras y Processos / Serie Religión, Madrid: Trotta, 1993, p. 756.

55 Idem, Do terror de Isaac..., Op. cit., p. 216. 


\subsection{As razões da fé}

Que sentido tem a realidade se ela é inevitavelmente assim? Quer dizer que o mundo é bom, porém a seu modo? É, ao mesmo tempo, capaz de realizações grandiosas, bem como passível de deslizar na própria violência e no horror.

Este é o momento de buscar na fé o sentido da própria vida no mundo. Importa mostrar as razões da própria fé. Esta nos diz que Deus criou-nos por amor, livres para amá-lo; quis nos tornar participantes de sua felicidade. Mesmo se o mal é uma possibilidade, haja vista a finitude inerente à realidade na qual vivemos, a experiência de fé nos introduz na certeza do amor criador de Deus. É dele a vitória final sobre toda forma de mal. Isto fez com que Santo Agostinho chegasse a afirmar que "Deus onipotente..., sendo como é sumamente bom, não permitiria que houvesse algum mal em suas obras se não fosse tão onipotente e tão bom o suficiente para poder extrair o bem até do mal" ${ }^{56}$.

O amor de Deus não se opõe ao respeito da liberdade humana. Nem por isso deixa de ser aquilo que há de mais real, mesmo que nem sempre seja evidente à nossa percepção imediata. Há momentos que gritamos e, como Jesus, também sentimos surgir em nós o grito: "Por que me abandonaste?" No entanto, sabemos como a confiança, mesmo nas horas mais difíceis e cruéis, levou Jesus à afirmação: "Em tuas mãos entrego o meu espírito". Este itinerário nos aponta para a necessidade de reconquistar em nossa própria vida essa convicção que alimentou Jesus.

Jesus crucificado e ressuscitado torna-se o ponto de referência de nossa fé. "Uma vez que Jesus superou a dúvida e que sua confiança foi confirmada por Deus na ressurreição, para nós abriu-se já a certeza da fé; de tal forma que, por trás das nuvens da obscuridade histórica, sempre à espreita, podemos estar certos do incansável sol de amor que, para além delas, embora às vezes pareça eclipsada pelo mal, nunca se apaga nem nos abandona jamais" 57 . Portanto, como vemos, é na perspectiva de fé em Jesus Cristo que se apresenta o lugar legítimo para a discussão do mal. A discussão ou a busca de respostas não se detém numa evidência filosófica, porém mergulha no mistério, onde vai tateando a possível inteligibilidade. Apresentam-se dificuldades e escuridões, porém a difícil tarefa não é impossível.

Nós fazemos a experiência do amor de Deus enquanto mergulhados na realidade finita que somos e enquanto mediados pelo tempo. Haja vista a nossa situação de criaturas e imperfeitos, sabiamente uma

56 S. AGOSTINHO, Enchiridion de fide, spe et caritate, cap. 3.

A. TORRES QUEIRUGA, Op. cit., p. 232. 
pedagogia divina se instaura; esta já fora captada por Santo Irineu ao afirmar que "Deus nos conduzirá gradualmente à perfeição, como uma mãe que deve, primeiro, amamentar seu filho recém-nascido, e vai lhe dando, à medida que cresce, o alimento de que necessita" ${ }^{, 58}$. Intui-se, desta afirmação, que a temporalidade e a imperfeição nos apontam para a impossibilidade de uma criatura ser criada já pronta. É como dizer que é impossível, mesmo para Deus, criar uma liberdade finita já perfeita ${ }^{59}$. Nesta mesma linha de pensamento, Andrés Torres de Queiruga, afirma: "Se Deus criando-nos, por amor e, portanto, exclusivamente para nossa felicidade, não nos criou já completamente felizes, é simplesmente porque isso não é possível”"60.

Se, por um lado, não podemos negar a finitude, por outro lado, cremos na salvação. Esta aponta para a superação, para a libertação de todo mal, o que significa a superação da própria finitude. A reflexão teológica nos faz entrever, neste ponto, o caráter dinâmico da liberdade e da relação existente entre o Criador e a criatura. A liberdade, mesmo que esteja inevitavelmente exposta ao erro e à deficiência, descobre-se alimentada por uma ânsia de plenitude e realização, numa "aspiração infinita", insaciável, sem limites. O Criador, na sua relação com as criaturas, faz-se presente por um "amor preveniente", para conduzi-las à participação em sua glória. A criatura é chamada à comunhão com Deus, concretizada numa participação, na qual "Deus será tudo em todos", como nô-lo anuncia São Paulo $(1 \text { Cor } 15,28)^{61}$.

A criatura finita tem o mal como inerência inevitável. É como que um "pano de fundo obscuro",62. Esta situação a torna incapaz de alcançar a plenitude ou a salvação pelo seu próprio esforço ou por si mesma. 0 segredo, portanto, está em abrir-se à graça e à esperança da salvação em Jesus Cristo. "A atitude fundamental do cristão diante dessa realidade não é o medo diante do mal, mas a esperança na sua superação definitiva... A fé na criação atesta que tudo o que existe só existe pelo fato de que Deus o faz participar por amor e livremente de seu próprio ser" ${ }^{\text {63 }}$. O pressuposto é um Deus de ternura, misericordi-

58 Cf. S. IRINEU, Adv. haer., IV, 38,1.

59 Já $H$. de Lubac, numa obra de 1946, intitulada Surnaturel, tem levantado tais ques-tões, sendo acompanhado, bem mais tarde, por Hans Urs von Balthasar na obra Theodramatik, t. II/1 e IV, Einsiedeln, 1976, 1983.

60 Cf. A. TORRES QUEIRUGA, Op. cit., p. 242.

61 Ao falar de "aspiração infinita", Bernard Welte usa a expressão "infinitude finita". Com relação ao amor preveniente de Deus, K. Barth e E. Jüngel chegam a propor a expressão "infinitização" ou "eternização" da pessoa finita. Cf. Ibidem, pp. 244-249. ${ }^{62}$ Idem, Recuperar a salvação: por uma interpretação libertadora da experiência cristã, São Paulo: Paulus, 1999, pp. 155-166.

${ }^{63}$ W. KASPER, O problema teológico do mal, in W. KASPER / K. LEHMANN / K. KERTELGE / J. MISCHO, Diabo, demônios, possessão: da realidade do mal, São Paulo: Loyola, 1992, pp. 55-56. 
oso, que não se contenta com a morte do pecador, mas quer que ele viva $^{64}$. Há, portanto, uma dinâmica positiva da fé, fundada num Deus que cria por amor, apoiando sempre a criatura em sua caminhada até a comunhão final. Para E. Schillebeeckx, este Deus é o anti-mal; Ele nos apoia na luta contra o mal $^{65}$.

Importa deixar-nos mover pela graça de Deus que já nos foi dada. Numa resposta livre e decidida, cabe-nos assumir, junto com Deus, a luta contra o mal. "Crer é aqui, por definição, atuar, inserindo-se na ação criadora e salvadora de Deus, combatendo aquilo que se opõe à nossa realização e à dos demais" "66. Não é por acaso que o amor ao próximo seja o centro da fé cristã; junto com o amor a Deus, ele constitui o eixo central ou a seiva que a tudo "carrega" de vida, realizando o projeto de Deus.

Mesmo sabendo que nossas realizações não esgotam o Reino de Deus, temos consciência de que importa buscar "o Reino de Deus e a sua justiça" (Mt 6,33). Importa fazer com que este Reino se torne presente já. Há uma tensão escatológica que se estabelece; esta "transforma-se em missão, para que o Reino se afirme de modo crescente, aqui e agora"67.

\section{Conclusão}

O mal nos desafia. Porém, não vamos "bater em retirada" diante das sombras e das exigências que se apresentam. Sabemos, na experiência de fé, que "tudo, mesmo o mal, depende da sabedoria de Deus e está incluído no seu desígnio criador-salvador"68. Mesmo que a razão humana não consiga penetrar no último porquê da existência do mal, sabemos que encontramos saída na escuta atenta da palavra que Deus dirige ao coração angustiado e sofrido. É Deus quem resgata o ser humano da passividade e da alienação, chamando-o ao amor, ao serviço. Hoje, importa "reabilitar o amor...; existe nele um verdadeiro projeto cristão e mesmo um projeto de Igreja"69.

"A glória de Deus é o homem vivo e a vida do homem é a visão de Deus" ${ }^{\prime 70}$. Sem escapismos, precisamos reconhecer a iniciativa de

64 Cf. SI 103,8; Ez 18,23-32.

${ }^{65}$ E. SCHILLEBEECKX, Jesús: la história de un viviente, Madrid: Cristiandad, 1981, pp. 105-162.

66 A. TORRES QUEIRUGA, Do terror de Isaac..., Op. cit., p. 255.

${ }^{67}$ Cf. JOÃO PAULO II, Exortação apostólica 'Vita Consecrata' = Documentos Pontifícios $n^{\circ} 269$, Petrópolis: Vozes, 1996, $n^{\circ} 27$.

68 Cf. A. G. RUBIO, Op. cit., p. 549.

${ }^{69}$ Cf. A. GESCHÉ, "Dieu et le mal", in VVAA, Péché collectif et responsabilité, Buxelles: Facultés Universitaires Saint-Louis, 1986, p.121.

70 S. IRINEU, Op. cit., IV, 20,7. 
Deus que nos chama para a sua promessa de vida, ligada à noção de justiça, cuja realização é a verdade última sobre o ser humano, o seu julgamento ${ }^{71}$. Nisto toma pulso o realismo cristão em face ao mal. Disponível para realizar a vontade de Deus, o cristão assume a luta contra o mal e todas as suas causas. Mesmo que persista o seu caráter misterioso, não se deixa tomar nem pelo ceticismo nem pelo otimismo ingênuo. A realidade é desafiadora sim, porém, a confiança em Deus leva-o a crer que a última palavra não é morte, nem pecado ou degradação, mas vida, amor, graça divina.

A atitude fundamental será, na verdade, a do amor-serviço gratuito. Este é o convite do Deus-Ágape; este é o chamado de Jesus. Sela-se aí o compromisso de lutar contra o mal. Nunca no sentido de querer vencer o mal com o mal, do "olho por olho, dente por dente". A recomendação de Jesus Cristo é clara. Trata-se de retribuir o mal com o bem. "Vencer o mal com o bem"72, mesmo na relação com os inimigos, significa ser capaz da experiência da gratuidade e de um amor-serviço, sem olhar a quem.

A luta contra o mal não pode ficar restrita apenas às relações interpessoais, mas urge que se estenda aos sistemas e estruturas. Toda forma de desumanização, de injustiça, de discriminação, de dominação e de exploração encontra a firme decisão contrária do cristão, numa dessolidarização do sistema injusto, numa deslegitimação do mesmo. Não nos falte a coragem evangélica de denunciar as situações perversas e desumanizadoras no nível estrutural.

O itinerário a ser trilhado é o de Jesus. Ele mostra o caminho que o discípulo é chamado a seguir. "Jesus procedeu contra a ignorância e confusão dos homens ensinando-os. Quantas vezes não se sublinha nos Evangelhos que Jesus os ensinava (Mc 2,13 e passim), que ensinava o povo como de costume (Mc 10,1). Agiu contra a doença curando (Mc 1,34 e passim). Agiu contra o pecado perdoando (Mc 2,5; Lc 7,47; cf. Lc 23,34) e não cometendo, ele mesmo, nenhum pecado (Jo 8,46; 1Pd 2,22). Agiu contra o mal fazendo unicamente o bem (Mc 3,4; At 10,38). Agiu contra o ódio (Jo 7,7; 15,18), amando até a morte ( $\operatorname{Rm} 5,8 ; 8,37)$. Ao invés de julgar o mundo, o salvou (Jo 3,17$)^{\text {,73. }}$.

A luta contra o mal nunca será efetiva se pretender estigmatizar territórios, povos ou nações, na presunção de que o bem esteja de um lado e o mal do outro. Todo e qualquer ser humano, povo ou nação

\footnotetext{
${ }^{71}$ Cf. I. CHAREIRE, Éthique et grâce: Contribution à une anthropologie chrétienne, Paris: Cerf, 1998, p. 70.

$72 \mathrm{Rm} \mathrm{12,21.}$

73 H. HAAG, Op. cit., p. 278; cf. A. G. RUBIO, Op. cit., p. 554.
} 
traz dentro de si o bem e o mal. 0 discurso maniqueísta que queira pleitear tal divisão do mundo cria, na verdade, um clima propício para o aumento da violência. "O bem não possui apenas um representante legítimo (em geral, o modelo ocidental)"74. Torna-se extremamente oportuno lembrar o que afirmara São Gregório de Nissa: “Na realidade, há uma confusão na natureza do mal: suas profundezas escondem a perdição, como um disfarce astuto, mas a aparência é enganadora, pois apresenta de alguma forma as aparências do bem",75.

Nilo Agostini OFM - Doutor em Teologia pela Faculdade de Teologia Católica da Universidade de Ciências Humanas de Strasbourg, França. Atualmente, trabalha como Professor de Teologia Moral na PUC-Rio, onde é o Coordenador da Graduação do Departamento de Teologia, e no Instituto Teológico Franciscano de Petrópolis, RJ. Tem ampla publicação (seis livros e dezenas de artigos). Seu livro Teologia Moral: 0 que você precisa viver e saber (Ed. Vozes, Petrópolis) encontra-se na 6a edição. Durante 11 anos, foi o Redator da Revista de Espiritualidade Grande Sinal.

Endereços: Departamento de Teologia - PUC-Rio Rua

Marquês de São Vicente, 225 - Gávea

22453-900 Rio de Janeiro RJ

e-mail: agostini@rdc.puc-rio.br

Instituto Teológico Franciscano

Caixa Postal 90023

25689-900 Petrópolis RJ e-

mail: agostini@itf.org.br

${ }_{74}$ P. D. FARAH, "Para analistas, maniqueísmo favorece violência”, Folha de São Paulo, Caderno Especial, 13 de setembro de 2001, p. 16.

${ }^{75}$ S. GRÉGOIRE DE NYSSE, "La création de I'homme” in DDB, 1982, p. 114; cf. G. LEROY, "La présence du mal et de la mort dans la création", Contact - Revue française de l'Orthodoxie XXXVIII (1986) 183. 